\title{
Design, Development and Testing of Screw Press Machine for Paddy Straw under Ground Digester
}

\author{
Jasvarinder Chalotra* and Sarbjit Singh Sooch
}

Department of Renewable Energy Engineering, College of Agricultural Engineering \& Technology, Punjab Agricultural University, Ludhiana- 141004, Punjab (India)

*Corresponding author

\begin{tabular}{|c|c|}
\hline & A B S T R A C T \\
\hline Keywords & \multirow{4}{*}{$\begin{array}{l}\text { The main objective of this research is to develop a machine for removing } \\
\text { solid bio-digested slurry from the underground digester. In this research, a } \\
\text { concrete digester having depth } 10 \text { feet } x 10 \text { diameter was constructed and } \\
\text { installed under the ground for biogas production. The storage capacity of } \\
\text { this digester is } 2000 \mathrm{~kg} \text {. The application of this digester is biogas } \\
\text { production and an alternative of LPG cylinder. The biomass used is } \\
\text { chopped paddy straw, which gets converted into solid bio-digested slurry } \\
\text { after an interval of three months. The main problem was removal of this } \\
\text { solid bio-digested. To overcome this, a machine was developed according } \\
\text { to dimensions of digester and tested. A screw press machine of length } 11 \\
\text { feet and } 4 \text { inches diameter is designed and fabricated in that way, so that it } \\
\text { can be handled by a single person. }\end{array}$} \\
\hline $\begin{array}{l}\text { Underground } \\
\text { digester, Paddy } \\
\text { straw management, } \\
\text { Screw press } \\
\text { machine, Well } \\
\text { chopped paddy } \\
\text { straw }\end{array}$ & \\
\hline Article Info & \\
\hline $\begin{array}{l}\text { Accepted: } \\
\text { 04 February } 2019 \\
\text { Available Online: } \\
10 \text { March } 2019\end{array}$ & \\
\hline
\end{tabular}

\section{Introduction}

Paddy straw management is the focus area of government. Several projects and policies are adopted to overcome this problem of burning caused by paddy straw in North India. Paddy straw digester is the developed technique to produce biogas by utilizing paddy straw waste collected from the field. The paddy straw with cow dung loaded in the digester initially. After 7-8 days it starts producing biogas in the absence of oxygen by anaerobic digestion. This project is very beneficial for domestic purpose as well as power generation. The digester produces biogas at the rate of 6 cubic meters daily, which is sufficient for family size 7 to 8 members. After it stop producing biogas, the paddy straw gets converted into solid bio-digested slurry. This solid slurry further used as manure in the farm fields.

Fabrication depends up on the designs. Due to automation mechanical industry as well as agriculture industry is also adopting new concepts to increase the production by time reduction. Every new project is different so 
obviously the requirements become special. For new and special requirements the machines are not available in the market. Only for standard work the machine are easily available in market. In this research project the major requirement is removal of material from the depth. There are various techniques for lifting i.e. hydraulics, conveyer system and screw press. For this project the screw press technology becomes feasible in the end.

\section{Statement of the problem}

The paddy straw digester is fabricated underground. The digester after filling with $1600 \mathrm{~kg}$ paddy straw and $400 \mathrm{~kg}$ cow dung start producing biogas for three months. After three months it gets converted into solid biodigested slurry. There is no standard size machine available in market which can be used for removal of this solid slurry. So the major problem is removal of material. Without it, project is not considered completed. This is the reason for developing machine for this digester.

\section{Significance of the project}

The government of India is planning for introducing the plant at domestic level. This is the alternative of LPG cylinders. Biogas is the natural source of energy as well as cheapest to others. Paddy straw is also the major problem, after harvesting majority of farmers burns their field and this raises the problem of air pollution and other diseases caused by smoke. The planning of government is to utilize the paddy straw waste in the form of cooking gas as well as power generation.

At present, all crop residues like paddy straw, potato tendrils, vegetable plants and tree leaves are being burnt in the fields just to make the fields clean for the next crops in short time. These crop wastes can be valuable fuel for kitchen the kitchen/ power generation
[1]. Although at present, some of the crop residues are being used for power generation using thermal method which not only create atmospheric pollution but also produce a huge amount of ash for which disposal becomes a headache. Research work indicates that open field burning of crop residue is a common practice in many countries [2]. Such crop residues may be digested by anaerobic means for the production of methane gas as a fuel for the kitchen as well as for power generation. The latest method of anaerobic digestion i.e. dry fermentation of organic wastes can be carried out which require little labor and produce a large amount of methane for a period of 3-4 months.

The digested material so produced from such anaerobic digestion is good quality manure, ready for use in fields. Rice husk used as a valued added raw material for different purposes. It possesses various properties that make them suitable for bio-ethanol production [2]. The ash of rice husk has properties of bricks [3]. The rice husks are used in road constructions and other useful purposes [4]. The carriage of digested material is not difficult as it can be carried in baskets for loading in tractor trolley.

\section{Materials and Methods}

Attempts have been made at "Department of Renewable Energy Engineering, Punjab Agricultural University, Ludhiana, to construct masonry structure as digester. The details of plant are given in Figure 1. The life of structure is more than 20 years. The advantage of masonry structure is that the whole structure is underground, on which cold would have little effect in winter. The complete project drawing is shown in Figure 1 .

In this section the design, fabrication and testing of machine is discussed. 


\section{Design of machine}

Design is the base of machine. The removal of solid bio-digested slurry (SBDS) was very difficult task. The major requirement of the project was to develop a handy machine according to dimensions of underground digester. There is only one way for filling and removal of material, so the machine was designed 11 feet long and 4 inch spiral blades welded were welded all around it.

A single phase electric motor was bolted on the top which rotate the shaft and lift the material from the depth and throws it outside on the ground. 11 feet long shaft was covered with CRC pipe as well as the motor was covered with safety cover. The design of machine is shown in the Figure 2. The weight of total machine is $27 \mathrm{~kg}$.

\section{Digester}

The machine was developed according to dimensions of digester and the dimensions of the digester were 10feet depth $\mathrm{x} 10$ feet depth. The structure is concrete based having 9 inch brick walling. A 3 feet mild steel manhole is provided on the top, the only way to enter the machine in digester. There is no other point provided for entering, because leakage proof system is the requirement of digester for continuous biogas production.

The storage capacity of the digester is $2000 \mathrm{~kg}$ i.e. $1600 \mathrm{~kg}$ paddy straw and $400 \mathrm{~kg}$ cow dung. Once material filled in this digester, it provides biogas continuously for three months. After three months period, new material is required for working of plant and the need of machine becomes a requirement.

The developed machine working in the digester is shown in Figure 3. From the top of the plant it is inserted by a laborer. After it get started, the blades welded on the shaft starts rotating and removes the solid bio-digested slurry.

\section{Testing}

After completion of interval of three months, the digester stops producing biogas. Paddy straw mix with cow dung gets converted into solid bio-digested slurry. The screw press machine attached with electric motor was inserted in the digester. The performance of the machine, time taken and design was tested in the field of Punjab Agricultural University.

\section{Results and Discussion}

This section shows the results taken during the testing of machine. The major requirement of project is removal of solid bio-digested slurry from plant. This machine is tested in the digester.

The weight removed, time taken, by the machine is noted during the testing. The data taken is shown in table 1. The results for design and fabrication is also discussed in this section of screw press. The fabrication of machine is shown in figure during working in Figure 4.

\section{Results for screw press machine tested in digester}

The machine is tested and find feasible for solid slurry removal. The material removed by this machine according to its size is very appreciable. The machines are tested for 18 hours in three days and remove $780 \mathrm{~kg}$ of weight. The machine is handled by a single person and it was found that the machine can easily be rotated in any direction. The data is noted after 15- 20 minutes according to measuring the weight. 
Table.1

\begin{tabular}{|c|c|c|}
\hline S.No. & $\begin{array}{l}\text { Solid Bio-digested slurry } \\
\text { removal in kilograms }\end{array}$ & $\begin{array}{l}\text { Time Taken in } \\
\text { Minutes }\end{array}$ \\
\hline 1 & $7 \mathrm{~kg}$ & $15 \mathrm{~min}$ \\
\hline 2 & $9 \mathrm{~kg}$ & $18 \mathrm{~min}$ \\
\hline 3 & $10 \mathrm{~kg}$ & $20 \mathrm{~min}$ \\
\hline 4 & $20 \mathrm{~kg}$ & $35 \mathrm{~min}$ \\
\hline 5 & $15 \mathrm{~kg}$ & $25 \mathrm{~min}$ \\
\hline 6 & $14 \mathrm{~kg}$ & $25 \min$ \\
\hline 7 & $9 \mathrm{~kg}$ & $15 \mathrm{~min}$ \\
\hline 8 & $10 \mathrm{~kg}$ & $15 \min$ \\
\hline 9 & $20 \mathrm{~kg}$ & $35 \mathrm{~min}$ \\
\hline 10 & $12 \mathrm{~kg}$ & $20 \min$ \\
\hline 11 & $10 \mathrm{~kg}$ & $18 \mathrm{~min}$ \\
\hline 12 & $14 \mathrm{~kg}$ & $22 \min$ \\
\hline 13 & $12 \mathrm{~kg}$ & $20 \mathrm{~min}$ \\
\hline 14 & $14 \mathrm{~kg}$ & $20 \mathrm{~min}$ \\
\hline 15 & $17 \mathrm{~kg}$ & $28 \mathrm{~min}$ \\
\hline 16 & $12 \mathrm{~kg}$ & $18 \min$ \\
\hline 17 & $11 \mathrm{~kg}$ & $18 \mathrm{~min}$ \\
\hline 18 & $10 \mathrm{~kg}$ & $16 \mathrm{~min}$ \\
\hline 19 & $9 \mathrm{~kg}$ & $14 \mathrm{~min}$ \\
\hline 20 & $12 \mathrm{~kg}$ & $15 \mathrm{~min}$ \\
\hline 21 & $11 \mathrm{~kg}$ & $15 \mathrm{~min}$ \\
\hline 22 & $10 \mathrm{~kg}$ & $13 \mathrm{~min}$ \\
\hline 23 & $9 \mathrm{~kg}$ & $15 \mathrm{~min}$ \\
\hline 24 & $8 \mathrm{~kg}$ & $12 \mathrm{~min}$ \\
\hline 25 & $7 \mathrm{~kg}$ & $10 \mathrm{~min}$ \\
\hline 26 & $6 \mathrm{~kg}$ & $10 \mathrm{~min}$ \\
\hline 27 & $7 \mathrm{~kg}$ & $10 \mathrm{~min}$ \\
\hline 28 & $11 \mathrm{~kg}$ & $20 \mathrm{~min}$ \\
\hline 29 & $12 \mathrm{~kg}$ & $18 \mathrm{~min}$ \\
\hline 30 & $11 \mathrm{~kg}$ & $20 \mathrm{~min}$ \\
\hline 31 & $14 \mathrm{~kg}$ & $20 \mathrm{~min}$ \\
\hline 32 & $17 \mathrm{~kg}$ & $28 \mathrm{~min}$ \\
\hline 33 & $12 \mathrm{~kg}$ & $18 \mathrm{~min}$ \\
\hline 34 & $11 \mathrm{~kg}$ & $18 \mathrm{~min}$ \\
\hline 35 & $10 \mathrm{~kg}$ & $16 \mathrm{~min}$ \\
\hline 36 & $9 \mathrm{~kg}$ & $14 \mathrm{~min}$ \\
\hline 37 & $12 \mathrm{~kg}$ & $15 \mathrm{~min}$ \\
\hline 38 & $11 \mathrm{~kg}$ & $15 \mathrm{~min}$ \\
\hline 39 & $10 \mathrm{~kg}$ & $13 \mathrm{~min}$ \\
\hline 40 & $9 \mathrm{~kg}$ & $15 \mathrm{~min}$ \\
\hline 41 & $8 \mathrm{~kg}$ & $12 \mathrm{~min}$ \\
\hline 42 & $7 \mathrm{~kg}$ & $10 \mathrm{~min}$ \\
\hline 43 & $6 \mathrm{~kg}$ & $10 \mathrm{~min}$ \\
\hline 44 & $7 \mathrm{~kg}$ & $10 \mathrm{~min}$ \\
\hline 45 & $11 \mathrm{~kg}$ & $20 \mathrm{~min}$ \\
\hline 46 & $12 \mathrm{~kg}$ & $18 \mathrm{~min}$ \\
\hline 47 & $11 \mathrm{~kg}$ & $20 \mathrm{~min}$ \\
\hline
\end{tabular}


Fig.1 Dimensions of Dry Fermentation Biogas Plant

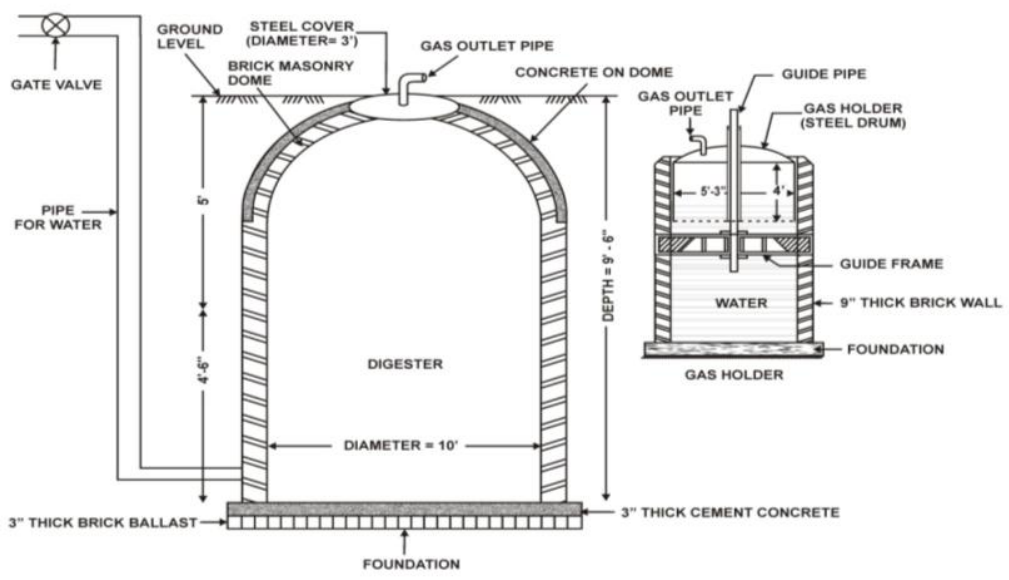

Fig.2 Design of screw press machine

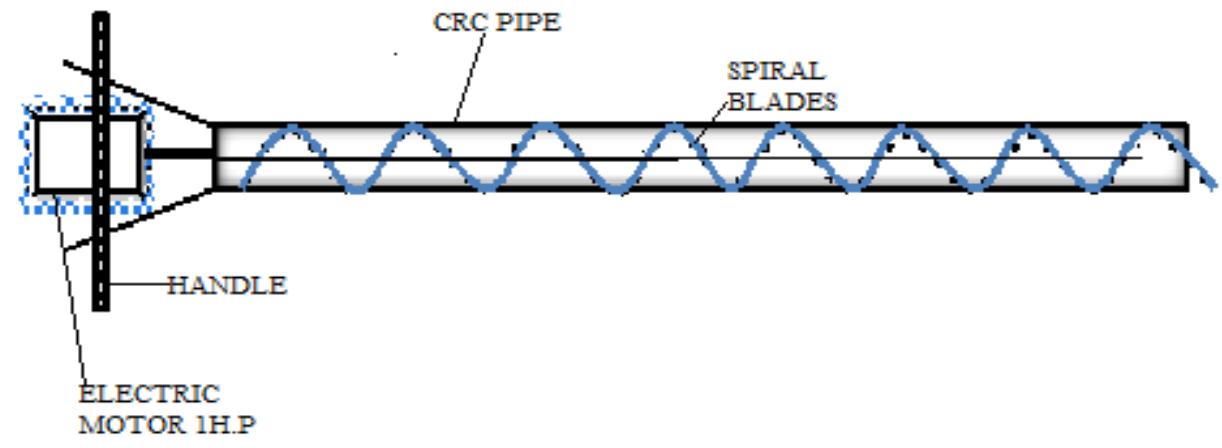

Fig.3 Screw press machine working in paddy straw digester

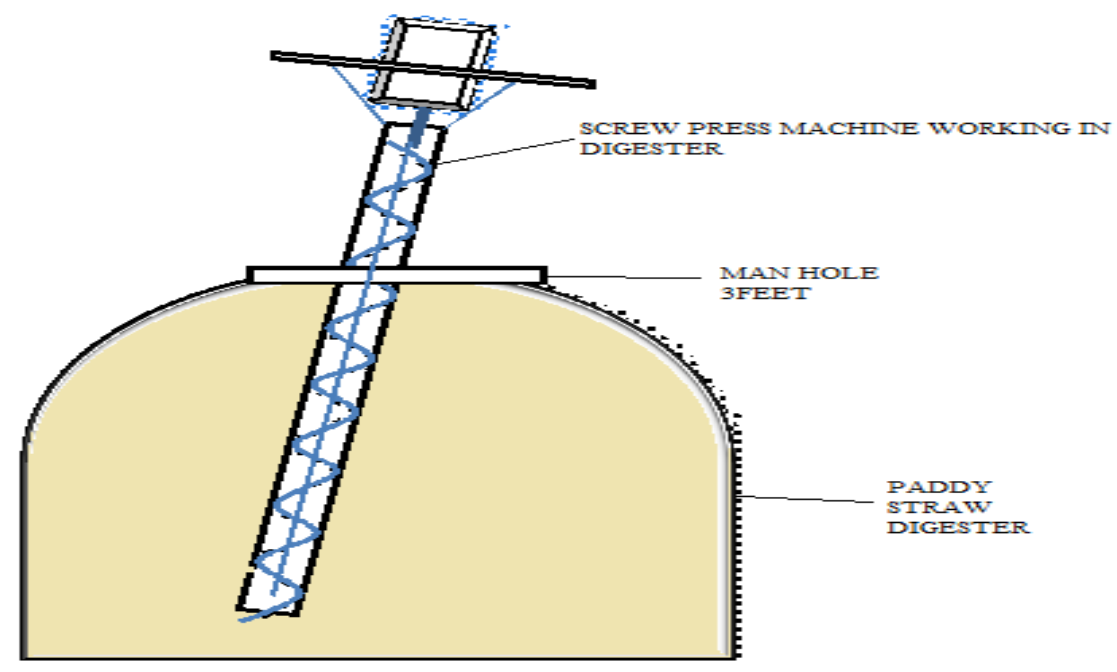


Fig.4 Screw press machine

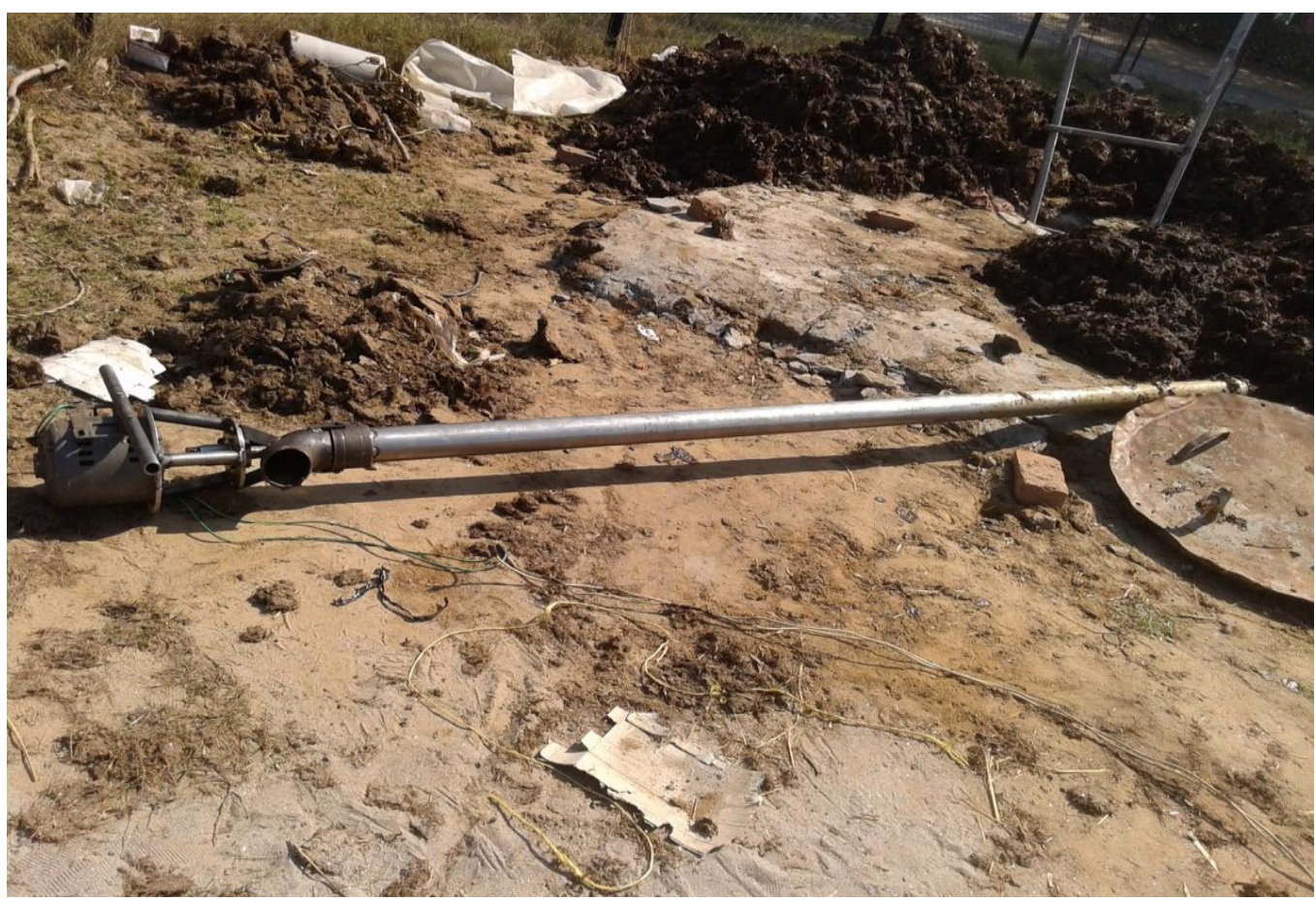

\section{Results for design of screw press machine}

This machine removed the physical load of labor.

No chattering was observed during operating of machine.

The welding was firm and no breakage observed.

The electric motor is firmly fixed and bolted on the top and finds no shaking of chattering. No accidental chances observed

CRC pipe and blades inside it worked smoothly, no wear and tear observed.

Easily transferrable due to its light weight. After work, the electric motor can be used for other works.

\section{Economics}

The cost of the machine including labor cost is just Rs.14,000. The rate of electric motor is also included in this. The project is for domestic usage, so the requirement is also cheap. This is very cheap concept and affordable by consumer

In conclusion, a cheapest machine is the major requirement. The machine can easily handle by a person, which reduces the labor as well as physical load. The machine fulfills the demands of project and makes it feasible for domestic use.

\section{References}

1. A. Apte, V. Cheernam, M. Kamat, S. Kamat, P. Kashikar, and H. Jeswani ,Potential of Using Kitchen Waste in a Biogas Plant, International Journal of Environmental Science and Development, Vol. 4, No. 4, August 2013 p370-374.

2. Sudiyani Y and Muryanto (2012), The potential of biomass waste feedstock for bioethanol production. Proceeding of International Conference on Sustainable Energy Engineering and Application Inna Garuda Hotel, Yogyakarta, 
Indonesia.

3. Sutas, J., A. Mana, L. Pitak, Effect of Rice Husk and Rice Husk Ash to Properties of Bricks, Procedia Engineering, vol 32, 2012, pp 10611067 , doi:10.1016/j.proeng.2012.02.055.

4. A.H. Patil, Akshay. R. Shirsat, Rushikesh, A. Phadke, Akshay, A. Mohire, Ganesh, H. Junawane, Navanath, N. Hake, Harshal Lunkad, Use of Rice Husk In Road Construction, Civil and Environmental Research, Vol.6, No.3, 2014.

5. Design Research on Hydraulic System of Working Device of a Forklift Liai Pan, Qiulei $\mathrm{Du}$ and Chunshan $\mathrm{He}$, College of Mechanical and Vehicle Engineering Changchun University, Changchun, China 2College of Special Education Changchun University, Changchun, China

6. Engyi Su, Present Situation and Development of the Light Small Carrying Vehicles, J. Logistics technology and application. 3(2003) 2527.

7. Qijun Zhang, Technology Development Trend of Foreign Forklift, J. Construction machinery technology and management. 12(1999) 36-38.

8. Yuanfang Tao, Design and Development Trend of Forklift, J. Forklift technology. 4(1995) 10-12.
9. M. O. Andreae and P. J. Crutzen, "Atmospherice Aerosols: Biogeochemical Sources and Role in Atmospheric Chemistry," Science, vol. 276, pp. 1052-1058, May 1997.

10. Office of Agricultural Economics of Thailand, "Thailand Country Report: Fundamental Agricultural Statistics 2010," 2011.

11. Lansing, S., Martin, J.F., Botero, R.B., da Silva, T.N., da Silva, E.D, (2010), Methane production in low-cost, unheated, plug-flow digesters treating swine manure and used cooking grease. Bioresour. Technol, 101, 4362-4370.

12. Centre for Application of Renewable Energy: (http://care.india.tripod.com, accessed May 2014).

13. Singh, S.P., Vatsa, D.K., Verma, H.N. (1997) Problems with biogas plants in Himachal Pradesh. Bioresour. Technol, 59, 69-71.

14. Shian, S.-T., Chang, M.-C., Ye, Y.-T., Chang, W. (1979), The construction of simple biogas digesters in the province of Szechwan, China. Agric. Wastes 1, 247-258.

15. [17. Ferrer, I., Garfí, M., Uggetti, E., Ferrer-Martí, L., Calderon, A., Velo, E, (2011), Biogas production in low-cost household digesters at the Peruvian Andes. Biomass Bioenergy, 35, 16681674.

\section{How to cite this article:}

Jasvarinder Chalotra and Sarbjit Singh Sooch. 2019. Design, Development and Testing of Screw Press Machine for Paddy Straw under Ground Digester. Int.J.Curr.Microbiol.App.Sci. 8(03): 138-144. doi: https://doi.org/10.20546/ijcmas.2019.803.019 